\title{
Northernmost Record of the Surgeonfish Acanthurus nigros (Teleostei: Acanthuridae) from Minamidaitojima Island, Southern Japan
}

\author{
Nozomi Hanahara ${ }^{1,2}$, Kei Miyamoto ${ }^{1}$, and Shin-ichiro Oka ${ }^{1}$ \\ ${ }^{1}$ Okinawa Churashima Research Center, Okinawa Churashima Foundation, Ishikawa 888, Motobu, Okinawa 905-0206, Japan \\ E-mail: n-hanahara@okichura.jp \\ ${ }^{2}$ Corresponding author
}

(Received 25 September 2020; Accepted 15 January 2021)

\begin{abstract}
A single specimen of surgeonfish (116.1 mm standard length) was collected from Minamidaitojima Island, southern Japan, and identified as Acanthurus nigros Günther, 1861 on the basis of morphological and genetic analyses. This specimen represents the northernmost and westernmost record of the species, about $1500 \mathrm{~km}$ from the nearest island (Pagan Island, Northern Mariana Islands) with previously confirmed record for this species. The new standard Japanese name "Nangokukurohagi" is proposed herein.
\end{abstract}

Key Words: Acanthurus nigroris, Okinawa, oceanic island, mitochondrial cytochrome $b$ gene, taxonomy, distribution.

\section{Introduction}

Surgeonfish of the genus Acanthurus Forsskål, 1775 (Teleostei: Acanthuridae) comprise more than 40 species from the tropical to temperate seas around the world, excluding the Mediterranean (Randall 2002; Fricke et al. 2020). Acanthurus is characterized by having a compressed and deep body, caudal peduncle with a single sharp folding spine on each side, small mouth, close-set and incisiform teeth with denticulate edges, dorsal and anal fins continuous and unnotched, small ctenoid scales, dorsal fin with six to nine (usually nine) spines and 22 to 33 rays, anal fin with three spines and 19 to 29 soft rays, pectoral fin with 15 to 17 rays, pelvic fin with one spine and five rays (Randall 1956).

Acanthurus nigros Günther, 1861 was originally described by Günther (1861) on the basis of the specimens collected from Vanuatu. This species was subsequently recognized as a synonym for Acanthurus nigroris Valenciennes in $\mathrm{Cu}$ vier and Valenciennes, 1835 (Randall 1956), but its validity was confirmed by Randall et al. (2011). Acanthurus nigros and $A$. nigroris are morphologically very similar, but can be distinguished by the counts of gill raker and the mitochondrial DNA cytochrome $b$ sequence divergence (Randall et al. 2011). Acanthurus nigroris is endemic to the Hawaiian Islands and Johnston Atoll, whereas A. nigros is widely distributed around the islands of the central and western Pacific Ocean, with Pagan Island, the Northern Mariana Islands, being the northernmost and westernmost record of A. nigros until now (Randall et al. 2011). In Japanese waters, Randall et al. (2011) reported A. nigros from Minamitorishima Island, the easternmost island of Japan, on the basis of more than 20 specimens. However, this species has never been recorded from Japanese waters since then, and standard Japanese name have not proposed for the species.

On 25 July 2017, a single specimen of A. nigros was collected from the Kameike Port in Minamidaitojima Island, southern Japan. This specimen represents the northernmost and westernmost record of the species, which is about $1500 \mathrm{~km}$ from the nearest island with confirmed record for this species. Herein, we describe this specimen and propose a new standard Japanese name "Nangoku-kurohagi" on the basis of the specimen.

\section{Materials and Methods}

Counts and measurements followed those described by Randall (1956) except for the measurement of caudal-fin spine length, which was renamed the caudal-peduncle spine length. Counts and measurements were made on the left side, except for gill rakers (counted on both sides). Measurements were made to the nearest $0.1 \mathrm{~mm}$ using a vernier caliper. Teeth were observed under a stereomicroscope (Nikon, SMZ645). The dorsal-, anal-, and caudal-fin rays and vertebrae were counted from radiographs. Standard length and head length were abbreviated as SL and HL, respectively. The specimen was deposited in the Okinawa Churashima Foundation (OCF), Japan.

Total DNA was extracted from the muscle of the $A$. nigros specimen using a "HotSHOT" method (Truett et al. 2000). A segment of the mitochondrial cytochrome $b$ gene was amplified using the heavy-strand primer 5'-GTG ACT TGA AAA ACC ACC GTT G-3' (Song et al. 1998) and the light-strand primer 5'-AAT AGG AAG TAT CAT TCG GGT TTG ATG-3' (Taberlet et al. 1992). Polymerase chain reaction (PCR) was conducted using a KOD FX Neo DNA polymerase kit (Toyobo, Osaka, Japan) under the following 

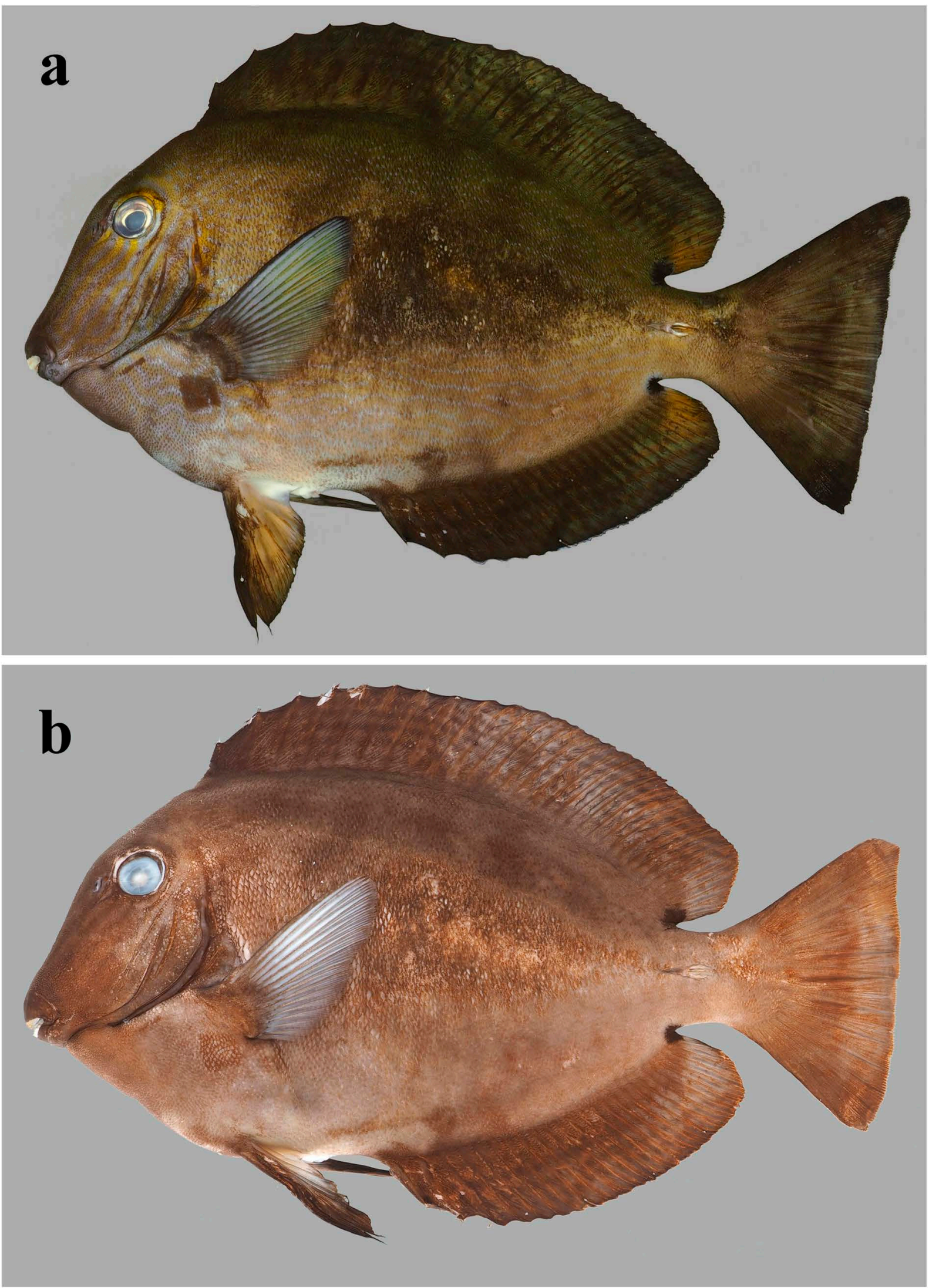

Fig. 1. Fresh (a) and formalin-preserved (b) specimen of Acanthurus nigros, OCF-P 3701, $116.1 \mathrm{~mm}$ standard length, Minamidaitojima Island, southern Japan. 
cycling conditions: $94^{\circ} \mathrm{C}$ for $2 \mathrm{~min}, 35$ cycles of denaturation at $98^{\circ} \mathrm{C}$ for $10 \mathrm{~s}$, annealing at $63^{\circ} \mathrm{C}$ for $30 \mathrm{~s}$, extension at $68^{\circ} \mathrm{C}$ for $60 \mathrm{~s}$, and a final extension at $68^{\circ} \mathrm{C}$ for $7 \mathrm{~min}$. PCRamplified fragments were sequenced by Sanger Sequencing Service (Macrogen Japan, Tokyo, Japan). The obtained sequence was deposited in the GenBank database (accession number: LC550289) and was compared with available sequences of $A$. nigros (HM242313-HM242317) and A. nigroris (HM24299-HM242303) reported by Randall et al. (2011), and with that of Acanthurus. nigrofuscus Forsskål, 1775 (KC623705). Sequences were aligned using the ClustalW algorithm (Thompson et al. 1994) in BioEdit software version 7.2.5 (Hall 1999). Phylogenetic reconstructions were performed based on the maximum likelihood method using MEGA7 software (Kumar et al. 2016) under the Tamura-Nei model (Tamura and Nei 1993).

\section{Acanthurus nigros Günther, 1861}

[New standard Japanese name: Nangoku-kurohagi] (Figs 1-3)

Material examined. OCF-P 3701, $116.1 \mathrm{~mm}$ SL, Kameike Port, Minamidaitojima Island, Okinawa, Japan $\left(25^{\circ} 48^{\prime} 47^{\prime \prime} \mathrm{N}\right.$, $\left.131^{\circ} 13^{\prime} 59^{\prime \prime} \mathrm{E}\right), 3 \mathrm{~m}$ depth, bait fishing, 25 July 2017 , collected by S. Oka and K. Miyamoto.

Description. Dorsal-fin rays IX, 25; anal-fin rays III, 25; pectoral-fin rays 16; pelvic-fin rays I, 5; principal caudal-fin rays 16, upper and lower procurrent caudal-fin rays 5; gill rakers 25 (on both left and right sides); vertebrae $9+13$.

Body depth, 53.7\% SL (1.9 in SL); body width, $17.0 \%$ SL; head length, 27.4\% SL; snout length, 21.4\% SL; orbit diameter, 7.8\% SL; interorbital width, 9.4\% SL; upper jaw length, $6.4 \% \mathrm{SL}$; groove in front of eye length, $4.3 \% \mathrm{SL}$; pre-dorsalfin length, $43.1 \%$ SL; second dorsal-fin spine length, $11.7 \%$ SL; ninth dorsal-fin spine length, $16.2 \%$ SL; pre-anal-fin length, 52.5\% SL; second anal-fin spine length, 10.2\% SL; third anal-fin spine length, $13.4 \%$ SL; caudal-peduncle depth, 12.2\% SL; caudal-peduncle spine length, 7.4\% SL (3.7 in HL); caudal-fin concavity, $7.8 \%$ SL (12.8 in SL).

Body deep and compressed. Dorsal profile of head strongly convex in front of eye; interorbital area strongly convex. Mouth small; teeth uniserial, incisiform, denticulate, and close-set, distal end of upper teeth rounded. A shallow groove extending obliquely in front of eyes; nostrils located in front of eye, anterior and posterior nostrils closely aligned; anterior nostril with flaps, anterior flap smaller than posterior flap which completely covers nostril aperture when folded forward; posterior nostril an elliptical opening.

Scales on body ctenoid; scaly sheath at base of dorsal and anal fins; lateral line obscure, approximately following dorsal contour at vertical around dorsal-fin origin and ending at front of caudal-peduncle spine socket.

Dorsal-fin origin above posterior edge of opercle; first spine very short and covered with skin; first soft rays unbranched. Anal-fin origin below eighth dorsal-fin spine origin; first spine very short and covered with skin; first three soft rays unbranched. Upper end of pectoral-fin base slight anterior to a vertical through dorsal-fin origin; third ray longest; upper two and lowermost rays unbranched. Pelvic fins reaching anal-fin origin; first soft ray longest. Caudal-fin

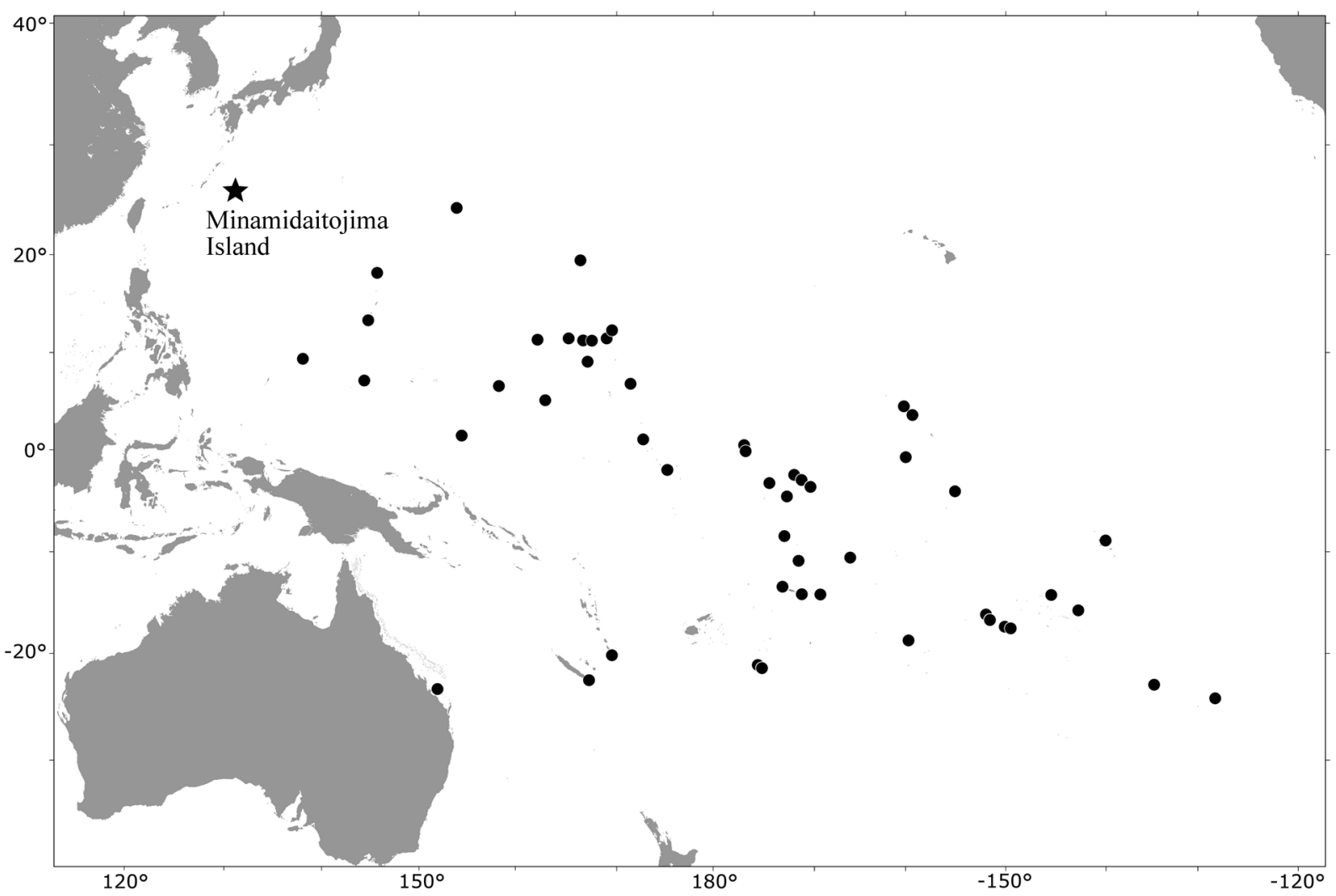

Fig. 2. Distributional records of Acanthurus nigros. Star and circles indicate present and previous records (Randall et al. 2011), respectively. 
slightly emarginate, upper and lower edges not elongate.

Coloration in fresh specimen (Fig. 1a). Body and head generally light to dark brown; body with light grayish dots dorsally, irregular and longitudinal light grayish stripes ventrally, narrower than brown interspaces; snout and opercular region with light grayish stripes paralleling outer margin of snout; iris yellow; pupil-sized black blotch at rear base of dorsal and anal fins; dorsal fin dark brown, five to seven faint grayish bands paralleling outer edge; anal fin dark brown, five faint grayish bands paralleling outer edge; pectoral fin yellowish light gray; pelvic fin light brown; caudal fin dark brown; caudal-peduncle spine light brown, its sheath white.

Coloration in preserved specimen (Fig. 1b; $10 \%$ formalin for 3 years). Body and head generally light to dark brown; body with small dark brown dots dorsally, dark brown stripes on suborbital region; dorsal and anal fins with dark brown bands; pupil-sized black blotch at rear base of dorsal and anal fins; sheath of caudal-peduncle spine light brown.

Distribution. This species has been recorded in a small region of the western Pacific Ocean (Minamidaitojima Island, Yap, Guam, Pagan, Vanuatu, and Great Barrier Reef) and widely in the central Pacific Ocean (except for the Hawaiian Islands and Johnston Atoll) (Randall et al. 2011; present study) (see also Fig. 2).

Remarks. The following morphological characteristics of our specimen closely matched the diagnostic features of A. nigros given by Randall et al. (2011): dorsal rays IX, 25; pectoral rays 16; gill rakers 25 ; teeth incisiform, denticulate, and close-set, the distal end of upper teeth rounded with 12 upper and 14 lower teeth; body depth 1.9 in SL; light to dark brown body with irregular, longitudinal, dotted stripes narrower than brown interspaces; suborbital and opercular region with stripes paralleling snout outline; pupil-sized black blotch at rear base of dorsal and anal fins; dorsal and anal fins with bands paralleling outer edge.

Acanthurus nigros and $A$. nigroris are closely similar in coloration: for example, light to dark brown body with irregular, longitudinal, dotted stripes narrower than brown interspaces; suborbital and opercular region with lines paralleling snout; pupil-sized black blotch at rear base of dorsal and anal fins; dorsal and anal fins with bands paralleling outer edge (Randall et al. 2011). However, A. nigros can be distinguished from $A$. nigroris by the counts of gill raker (21-25 vs. $26-31$ in A. nigroris), and mitochondrial DNA cytochrome $b$ sequence divergence (Randall et al. 2011). The counts of gill raker in our specimen (25) agreed with those of $A$. nigros. In addition, in the maximum likelihood tree based on a partial sequence (754bp) of the mitochondrial cytochrome $b$ gene, our specimen was placed within the clade of $A$. nigros, which was clearly separated from the clade of A. nigroris (Fig. 3). Therefore, our specimen was identified as $A$. nigros.

The number of anal-fin soft rays in our specimen (25) differed from that given by Randall et al. (2011) for A. nigros (22-24, mode 23), and matched with that of A. nigroris (2225, mode 24). In some species of Acanthurus, the number of anal soft rays shows relatively high intraspecific variation; for example, 25-28 in Acanthurus lineatus (Linnaeus, 1758), 19-22 in Acanthurus triostegus (Linnaeus, 1758), and 23-26 in Acanthurus thompsoni (Fowler, 1923) (Randall 1956). Therefore, the differentiation of the number of anal soft rays

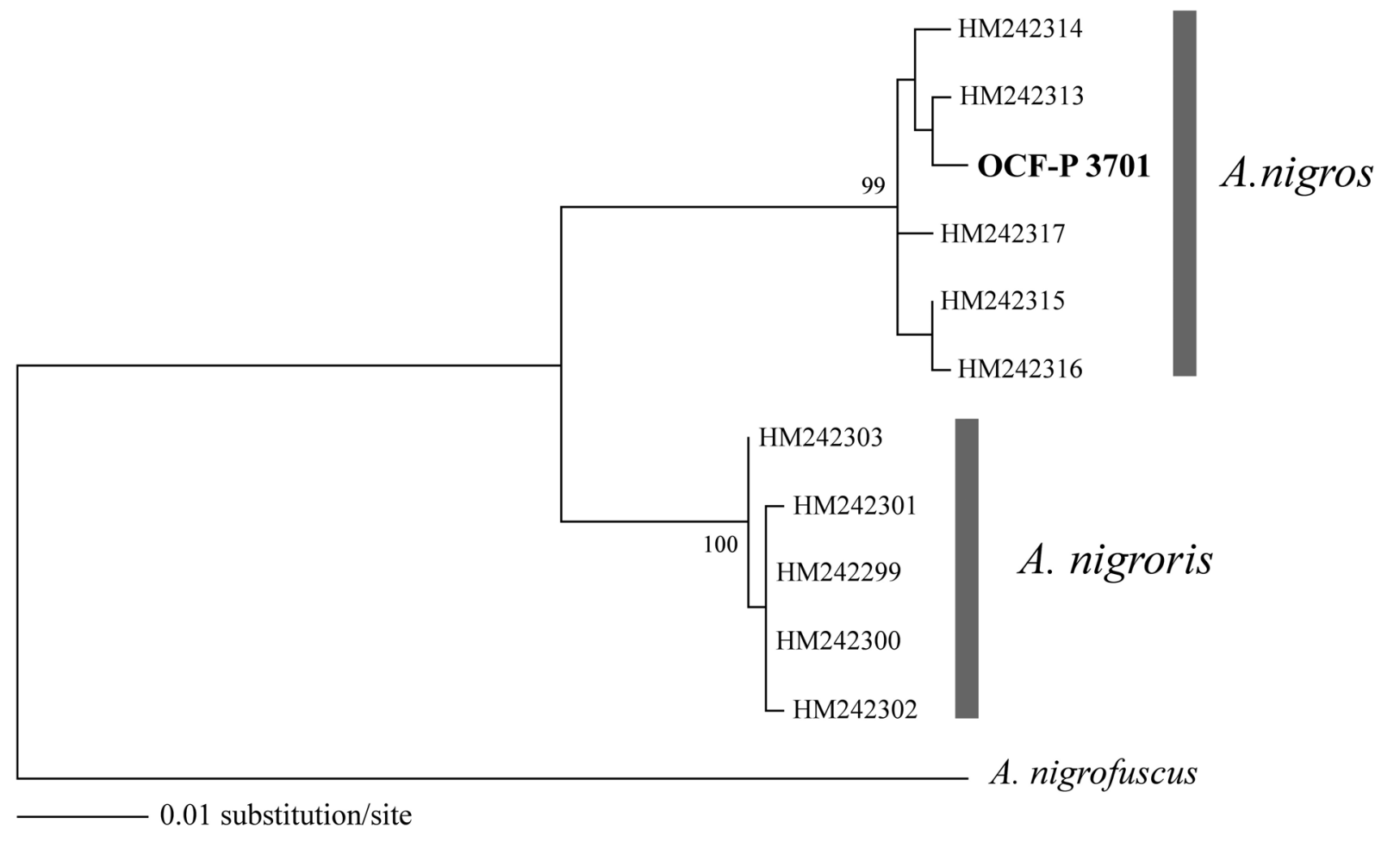

Fig. 3. Maximum likelihood tree based on partial sequence of the mitochondrial cytochrome $b$ gene (754bp) of Acanthurus nigros and A. nigroris. Numbers beside the internal branches indicate bootstrap probabilities ( $>95 \%)$ based on 1000 pseudoreplicates. 
between our count and that of Randall et al. (2011) was regarded as intraspecific variation. Similarly, the differences between our measurements and those reported by Randall et al. (2011) related to caudal-peduncle spine length (3.7 vs. $2.7-3.5$ in HL) and caudal-fin concavity (12.8 vs. $6.7-10.5$ in $\mathrm{HL}$ ) were also considered as intraspecific variations.

Among congeners known from the Japanese waters, $A$. nigros is similar to A. nigrofuscus in having light to dark brown body with irregular and longitudinal light grayish stripes, dorsal and anal fins with bands paralleling outer edges, and a black blotch at the rear bases of each dorsal and anal fin. However, the fresh specimen of $A$. nigros can be clearly distinguished from $A$. nigrofuscus by the presence of the lines parallel to the snout on the suborbital and opercular regions (vs. spots on those regions in A. nigrofuscus). In addition, these two species are distinguished by the following morphological characters: the size of the black blotch at the rear base of the dorsal fin (larger in $A$. nigros than in A. nigrofuscus); the presence or absence of a dark margin around the caudal-peduncle spine (absent in A. nigros vs. present in A. nigrofuscus); the posterior tips of the dorsal and anal fins (tips more pointed when these fins are elevated in A. nigrofuscus than in A. nigros); the bands on the dorsal and anal fins more visible in preserved specimens of A. nigros than in specimens of A. nigrofuscus (Randall 1956; present study).

Acanthurus nigros has been recorded mainly around the islands of the central Pacific Ocean (except for the Hawaiian Islands and Johnston Atoll) (Randall et al. 2011). Our specimen collected from Minamidaitojima Island represents the northernmost and westernmost record for the species, and the location was more than $1500 \mathrm{~km}$ away from the nearest island (Pagan Island, Northern Mariana Islands) previously recorded (Fig. 2). Minamidaitojima Island, oceanic island, is located approximately $300 \mathrm{~km}$ east of Okinawa Island in the Ryukyu Islands and is separated from the islands by the Ryukyu Trench. As stated by Koeda et al. (2015), marine fauna around Minamidaitojima Island is still not well understood. In addition to A. nigros, Acanthurus achilles, which are mainly distributed around the islands of the central Pacific Ocean, also inhabit Minamidaitojima Island (Shimada 2013). The geographical distribution of these species may be important in understanding the origins of the coastal fish fauna of the Daito Islands, including Minamidaitojima Island.

This species has never been listed in the comprehensive publications of Japanese fishes (e.g., Shimada 2013), although Randall et al. (2011) showed specimens of A. nigros collected from Minamitorishima (Marcus) Island in Japanese waters. The proposed new standard Japanese name is a combination of "nangoku", a Japanese name for tropical region, the distribution area of A. nigros, and "kurohagi", a common Japanese name for members of the genus Acanthurus.

Comparative materials. Acanthurus nigrofuscus: OCF-P 3702, 147.7 mm SL, Minamidaitojima Island, 25 July 2017;
URM-P 37816, $103.6 \mathrm{~mm}$ SL, Okinawa Island, 10 April 1997; URM-P 37817, $110.8 \mathrm{~mm}$ SL, Okinawa Island, 10 April 1997.

\section{Acknowledgments}

We thank K. Ueda and the staff at the OCF for their cooperation in this study. This study was funded by the Okinawa Churaumi Aquarium.

\section{References}

Fricke, R., Eschmeyer, W. N., and Van der Laan, R. 2020. Eschmeyer's Catalog of Fishes: Genera, Species, References. Available at http:// researcharchive.calacademy.org/research/ichthyology/catalog/ fishcatmain.asp (24 April 2020).

Günther, A. 1861. Catalogue of the fishes of the British Museum. Vol. 3. Taylor \& Francis, London, 586 pp.

Hall, T. A. 1999. BioEdit: a user-friendly biological sequence alignment editor and analysis program for Windows 95/98/NT. Nucleic Acids Symposium Series 41: 95-98.

Kumar, S., Stecher, G., and Tamura, K. 2016. MEGA7: Molecular evolutionary genetics analysis (MEGA) version 7.0 for bigger datasets. Molecular Biology and Evolution 33: 1870-1874.

Koeda, K., Chiba, S. N., and Motomura, H. 2015. First Japanese specimen-based record of Liopropoma tonstrinum (Teleostei: Serranidae), from Minami-daito Island, Daito Islands, southern Japan. Species Diversity 20: 19-22.

Randall, J. E. 1956. A revision of the surgeon fish genus Acanthurus. Pacific Science 10: 159-235.

Randall, J. E. 2002. Surgeonfishes of the World. Mutual Publishing and Bishop Museum Press, Honolulu, 123 pp.

Randall, J. E., DiBattista, J. D., and Wilcox, C. 2011. Acanthurus nigros Günther, a valid species of surgeonfish, distinct from the Hawaiian A. nigroris Valenciennes. Pacific Science 65: 265-275.

Shimada, K. 2013. Acanthuridae. Pp. 1619-1631, 2215-2218. In: Nakabo, T. (Ed.) Fishes of Japan with Pictorial Keys to the Species, Third Edition. Tokai University Press, Hadano. [In Japanese]

Song, C. B., Near, T. J., and Page, J. M. 1998. Phylogenetic relations among percid fishes as inferred from mitochondrial cytochrome $b$ DNA sequence data. Molecular Phylogenetics and Evolution 10: 343-353.

Taberlet, P., Meyer, A., and Bouvet, J. 1992. Unusual mitochondrial DNA polymorphism in two local populations of blue tit Parus caeruleus. Molecular Ecology 1: 27-36.

Tamura, K. and Nei, M. 1993. Estimation of the number of nucleotide substitutions in the control region of mitochondrial DNA in humans and chimpanzees. Molecular Biology and Evolution 10: 512-526.

Thompson, J. D., Higgins, D. G., and Gibson, T. J. 1994. CLUSTAL W: improving the sensitivity of progressive multiple sequence alignment through sequence weighting, position-specific gap penalties and weight matrix choice. Nucleic Acids Research 22: 4673-4680.

Truett, G. E., Heeger, P., Mynatt, R. L., Truett, A. A., Walker, J. A., and Warman, M. L. 2000. Preparation of PCR-quality mouse genomic DNA with hot sodium hydroxide and tris (HotSHOT). Biotechniques 29: 52-54. 